\title{
カヤー二測定器の使用実績
}

\author{
北越製紙株式会社新潟工場工務部 杉 浦 太 郎
}

\section{The Actual Data of Using KAJAANI Kappa Analyzer}

Taro Sugiura

Niigata Mill, Hokuetsu Paper Mills Ltd.

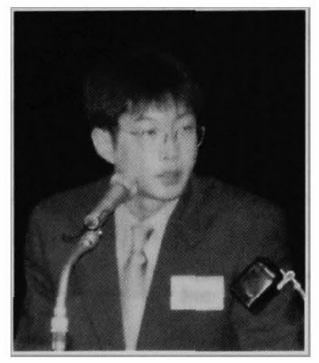

Hokuetu Niigata Mill started up the new coated paper machine (PM 8) in July 1998. To meet the needs of increasing pulp production, the new pulping plant that introduced ECF bleaching with D 0-Eo -DnD sequence ( $E$ line) started up.

At that time, for the purpose of stabilizing pulp quality. KAJAANI kappa analyzer was installed. This report describes actual data of using the analyzer.

分類： $\mathrm{F}_{2} \mathrm{KP}$ 蒸解, $\mathrm{V}_{2}$ 紙パルプ工程制御システム, $\mathrm{V}_{3}$ 紙パルプ工程計器およびセンサ

\section{1.はじめに}

北越製秖新鼬工場は、日産 500 トンのエスコ連釜系 列 (C 系) と日産 700 トンのカミヤ連釜系列 (D 系) の 2 つハパルフプラントを有していたが, 1998 年 7 月 のオンコーターマシン 8 号抄紙機の運転に先駆 け, 1997年 11 月にクウァナ社のITC (Isothermal Cooking）蒸解金, 1998 年 2 月に日産 1,200トンの新 晒ライン（E 系）を稼働させた。そして，老朽化し品 質や効率の低いC系を予備ラインとし，D系 $\mathrm{E}$ 系合 わせて 1,900 トンのパルプ製造能力を持つ工場へと生 まれ変わった。

新プラントは地域との共生を主眼とし環境負荷へ最 大の配虑をした結果, 世界の主流となりつつある ECF (Elemental Chlorine Free) 漂白, いわゆる無塩素漂 白を大規模プラントでしかもパルプ〜紙の一貫工場と しては日本で初めて採用した。

これに伴い, $\mathrm{ECF}$ パルプの品質安定と漂白薬品原 単位削隇を目的にオンラインカッパーアナライザーを 設置し監視及び制御を行うこととした。今回はその使
用実績を中心に報告する。

\section{2. アナライザー設置箇所}

ITC 蒸解釜〜E 系ファイバーラインのフローを図 1 に示す。また, アナライザー測定点については次の 4 個所である。

・鉒ブローライン

・ 未晒 $\mathrm{O}_{2}$ 段入口

·未晒 $\mathrm{O}_{2}$ 段出口

- 晒 D 0 段入口

釜フローラインから $\mathrm{O}_{2}$ 段出口までは監視用として 使用し，D0段入口においては制御用として使用して いる。また，実際の管理はカッパー洒ではなく $\mathrm{K}$ 価 として行っている。

\section{3. カッパー測定原理と初期設定}

\section{1 カッパー測定原理}

カヤーニカッパーアナライザーは光学測定原理によ ってパルプのカッパー価を測定する。キセノン光源か らの光はガラス測定セルの中を流れるサンプルに投射 

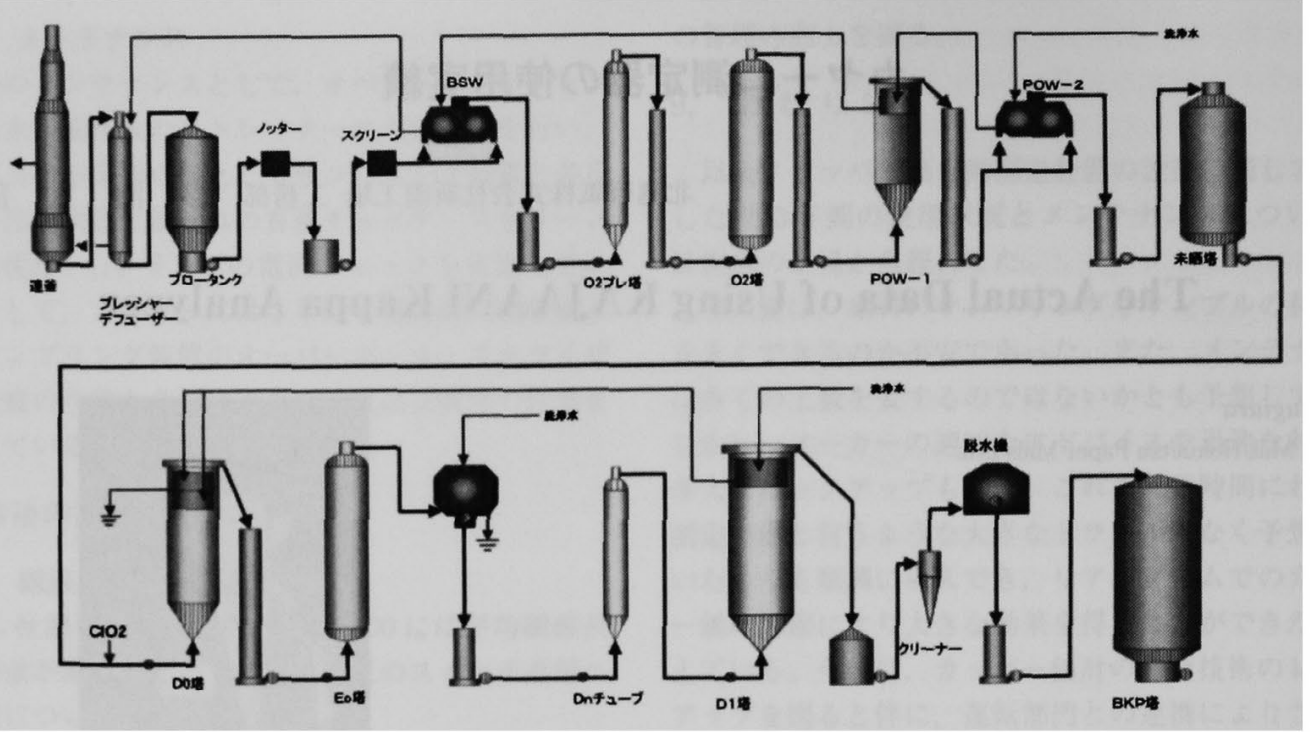

図１Ｅ系ファイバーラインフロー

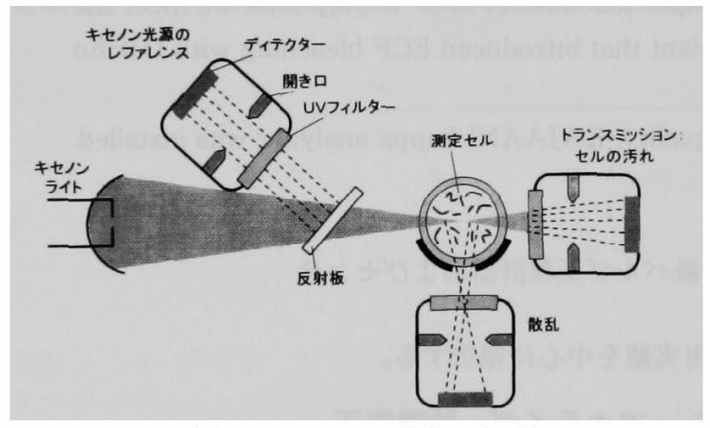

図 2 カッパー測定の原理

され, サンブルからの光の散乱によって現れた数種類 の波長の内, 一つの波長を特定しその波長において測 定される (図 2)。

\section{2 初期設定}

波長の特定は, アナライザーによる生データと試験 室での $\mathrm{K}$ 洒測定値との相関が最も良く取れている波 長を選択する。蒸解釜ブローラインを例に取り，各波 長における相関を図 3 に示し，その結果から最も良く 相関の取れている「Raw Data（3」の波長を初期設 定に採用した。

\section{3 特定波長における相関}

釜ブローラインと同様に， $\mathrm{O}_{2}$ 段入口， $\mathrm{O}_{2}$ 段出口， D 0 段入口の各測定点についても波長の特定を行い, 特定された波長に㧊けるアナライザー生データと試験 室での K 価測定値との相関について図 4 の結果が得
られた。

ほとんどの測定点において子想以上の相関係数が得 られ，特に釜ブローラインにおいては一般的に良い相 関係数が得られにくいといわれる中で 0.9 以上となっ た。D 0 入口での結果が低い值となったが，サンブル 点数を増やし繰り返し測定を行ったが図の值以上には 至らなかった。

\section{4 カッパー価測定值比較}

図 4 で得た各測定点での相関式により演算された $\mathrm{K}$ 価と試験室測定值とを比較した結果を図 5 に示す。

\section{4. アナライザーの信頼度}

$\mathrm{E}$ 系が稼㗢してから現在までの約 1 年半のデータの 中から, 稼働半年後, 1 年後, 1 年半後におけるアナラ イザー測定値と試験室測定値の比較を行った。データ は, 直 1 回の測定を行っている $\mathrm{O}_{2}$ 段入口, 出口につ いて調査した。使用開始後の時間経過に対しての誤差 範囲はそれほど変わってはおらず， $\mathrm{O}_{2}$ 段入口におい ては今のところ良好な結果を得ているが， $\mathrm{O}_{2}$ 段出口 では全体的にアナライザーの指示值が試験室測定值よ りも高めに出ている傾向が見られ，特に試験室測定値 の K 価が低くなるに連れ誤差が大きくなっている。 その原因は初期設定を行った際の $\mathrm{K}$ 価レベルと稼㖶 後における K 価レベルの差にあると考えられる。稼 働以降 $\mathrm{K}$ 価を低めに抑える操業に移行していった結 果 6〜7 付近で推移しているのに対し, 初期の設定は 7〜8 付近で行っており低 K 価域でのデータが不充分 
であったために得られた相関式が現状に適わないこと に起因しているものと思われる。現状に適合させるた めの式の修正に関しては切片の変更などで対処できる ものか様子を見ていくと共に今後の課題としたい。
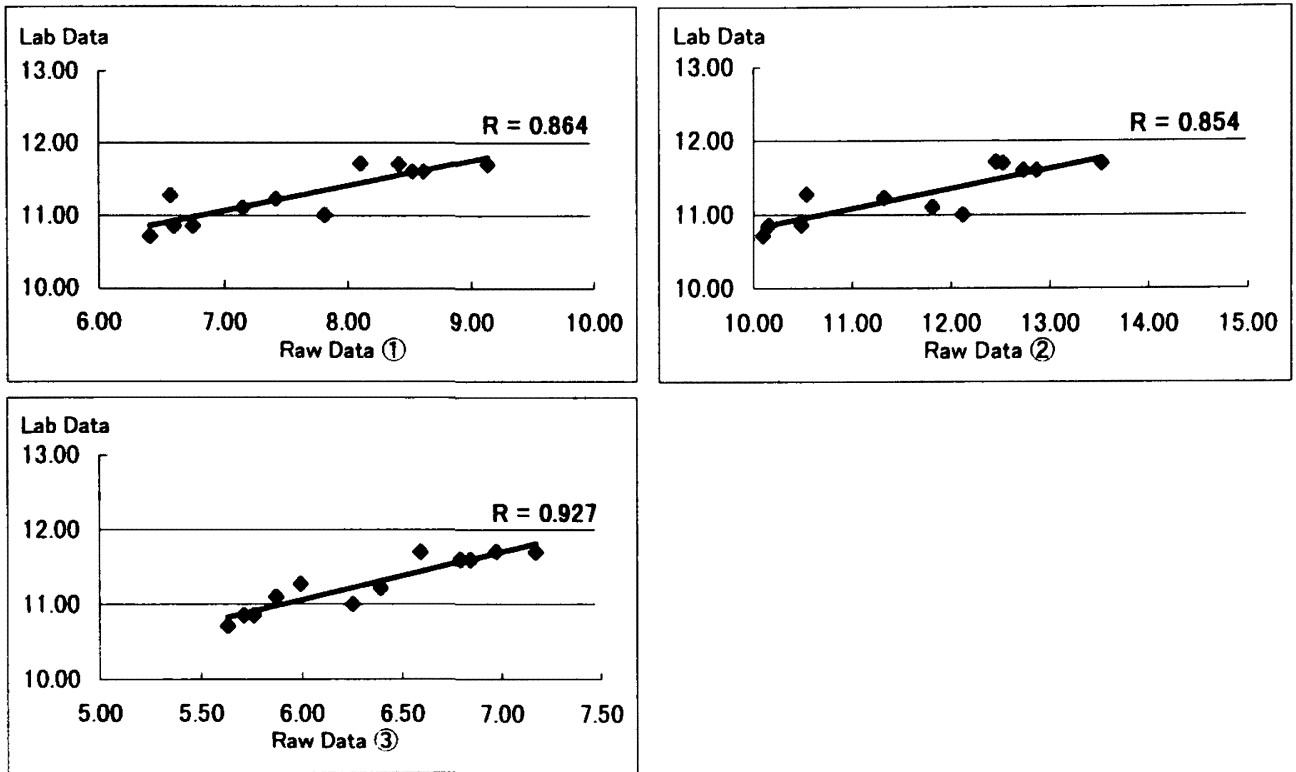

図 3 各波長におけるアナライザー生データと試験室データとの相関
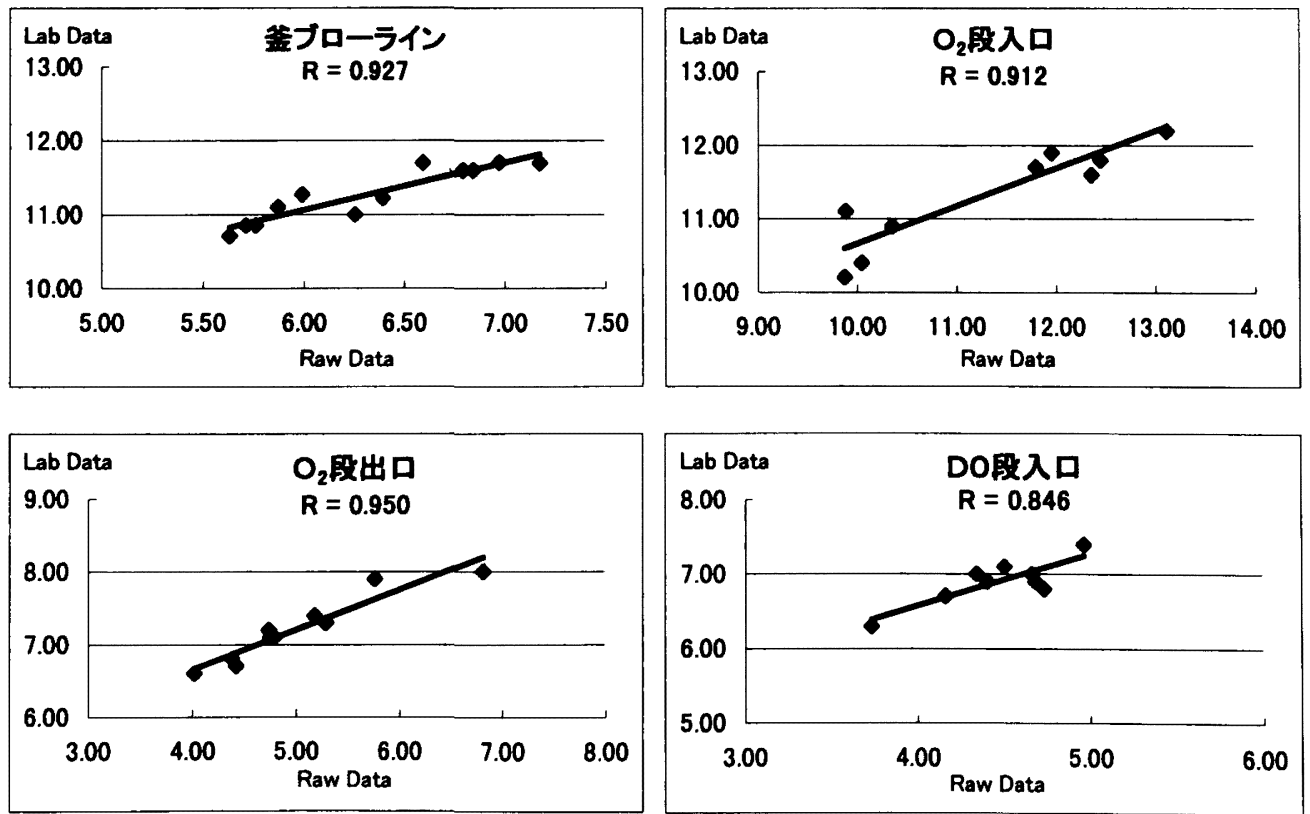

図 4 各測定点の特定波長における相関 
ペレーターの判断によって選択される。

通常は K 価制御を使用しており，D 0 出口白色度を 直 1 回測定し，結果によってオペレーターが「K 価を
1 下げるのに必要な $\mathrm{ClO}_{2}$ 添加率」を任意に与えてい る。操業が安定している時は調整する必要はないが, 材種変更や立ち上げ時などは $\mathrm{ClO}_{2}$ の添加が過剩過ぎ
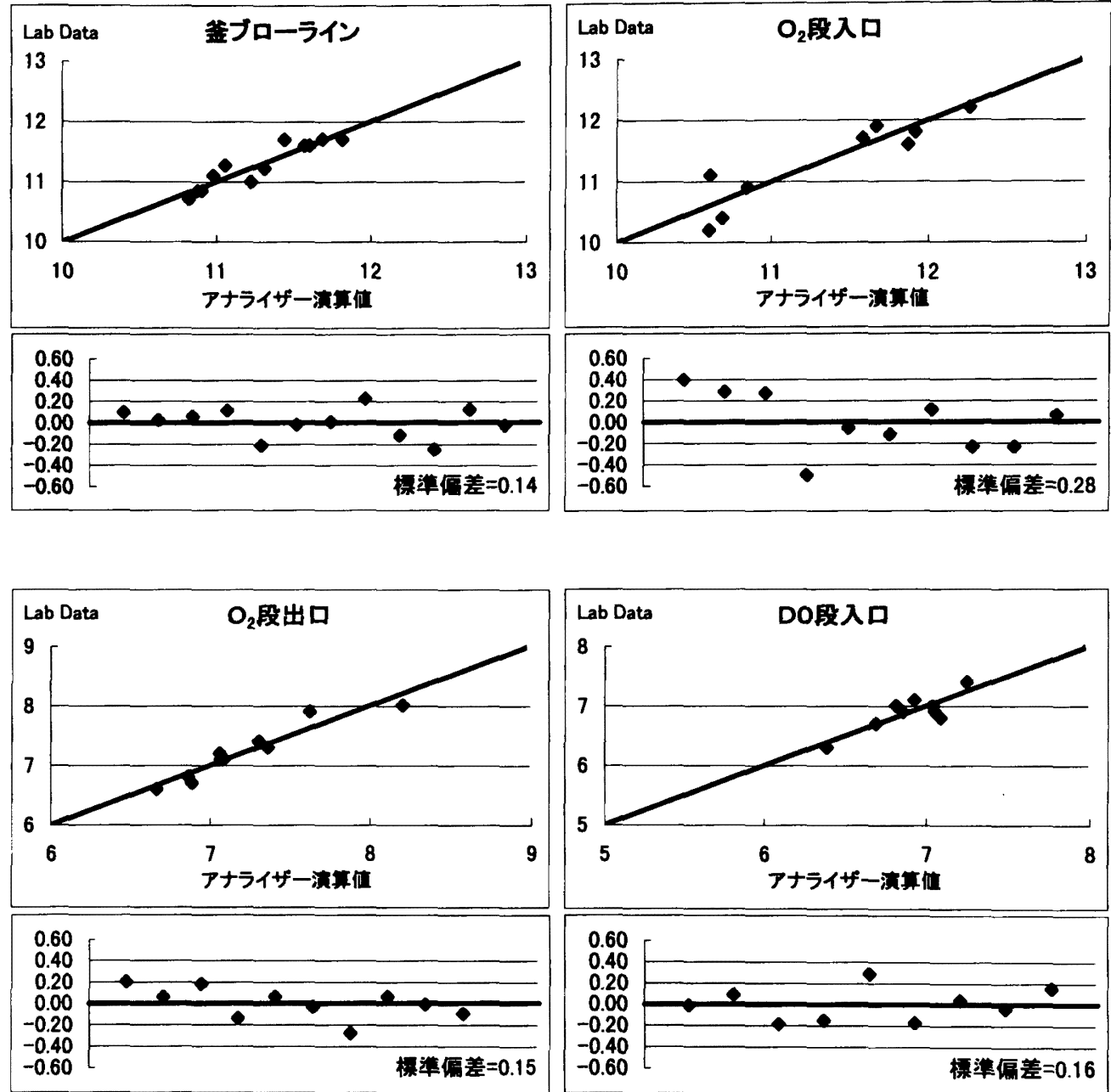

図 5 アナライザー演算值と試験室測定値の $\mathrm{K}$ 価比較
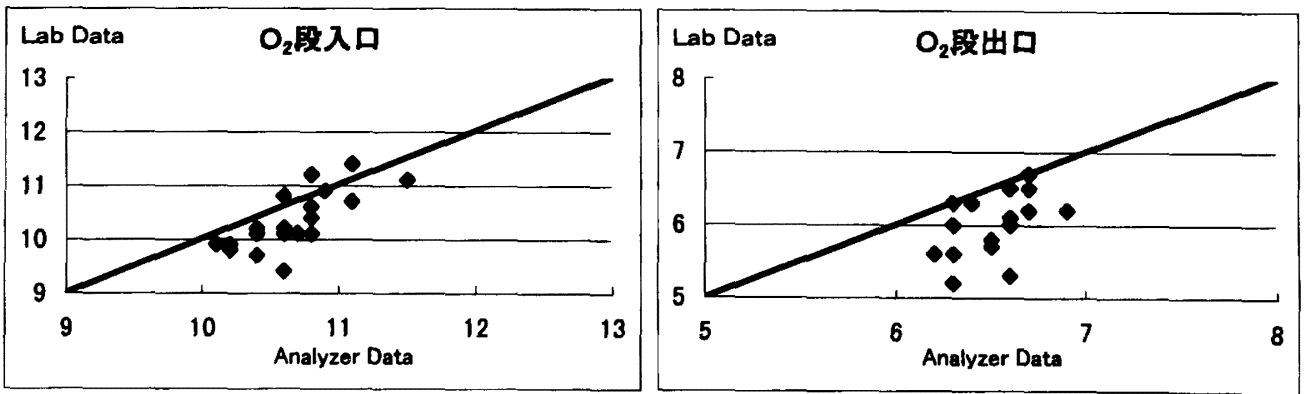

図 6 半年後の測定值比較 
ると逆に D 0 入口の白色度指示が低下することがある ため, オペレーターが濃度，白色，残塩などの操業因 子から実際に白色度が低下しているのかどうか判断し 調整している。

一方, 目標白色度制御では D 0 塔出口での予想白色 度の目標を設定し，それに対する指示值は D 0 塔入口 での各センサーの值を元に演算で作り予測制御を行う。

この両者の制御性に関して 2 ヶ月間での D 0 出口白
色度の比較を行ったところ，当社でのターゲット 70 〜 71 に対して白色度制御の方が若干バラッキ範囲は 広くなっており，僅かな差ではあるが $\mathrm{K}$ 侕制御の方 がバラッキが少ない結果となった。

\section{6. カッパー価測定器のトラブル事例}

カヤーニカッパーアナライザーを使用し始めてから 現在まで概ね順調に機能しているが，その中で僅かな
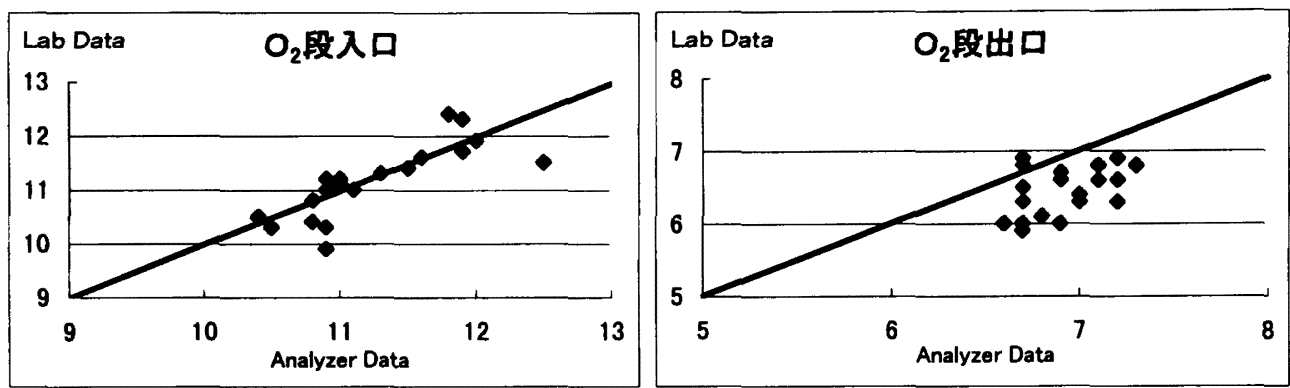

図 $7 \quad 1$ 年後の測定値比較
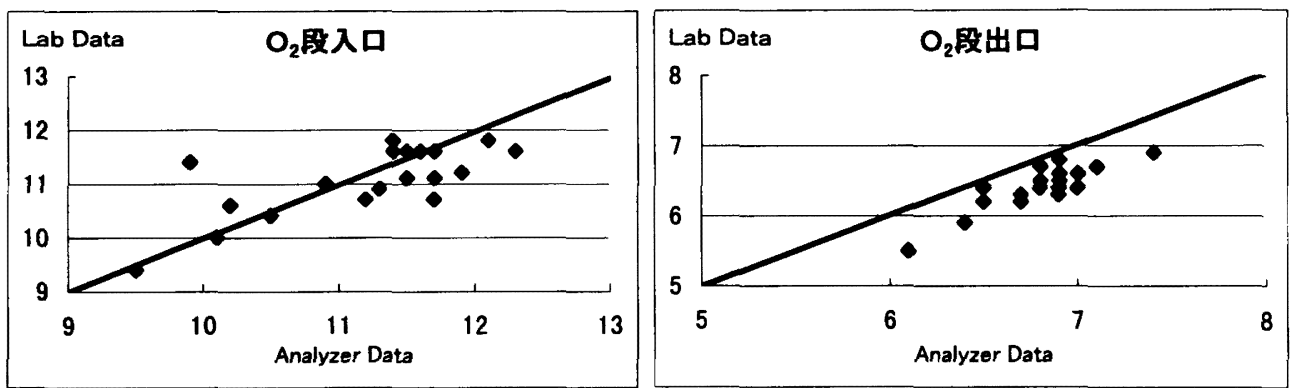

図 $8 \quad 1$ 年半後の測定值比較

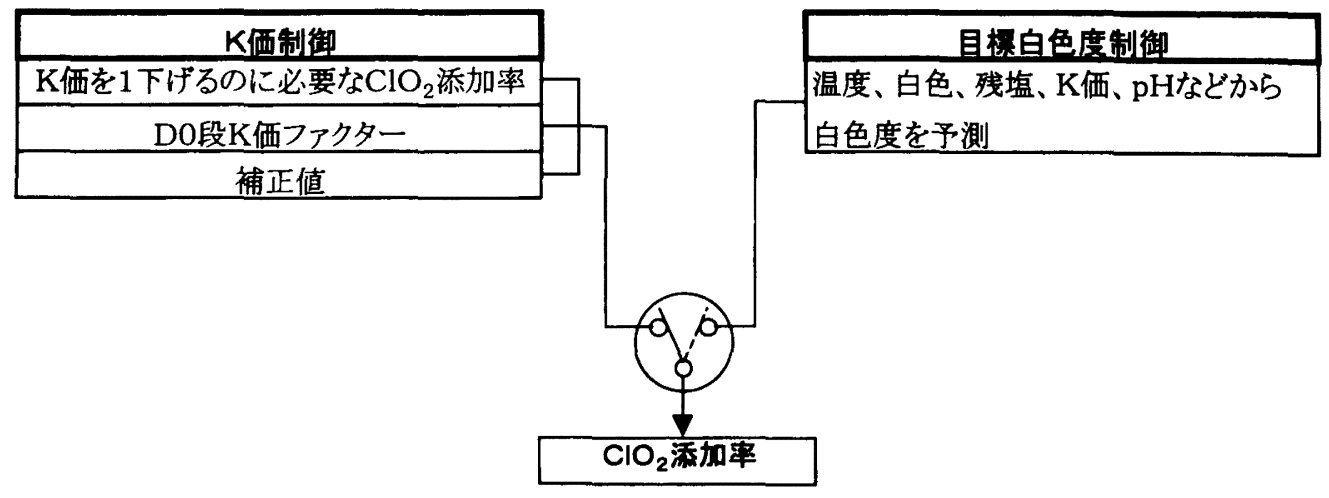

図 $9 \mathrm{D} 0$ 段の $\mathrm{ClO}_{2}$ 添加率制御 
がら起きたトラブルをいくつか報告する。

サンプルはサンプリング装置によってプロセス配管 から取り出され，あらかじめ設定した一定周期で水圧 によってアナライザーに送られるが，この段階でのト ラブルがほとんどである。

・アナライザーに送られるサンブル搬送用の水は昇 圧された後減圧弁によって減圧され一定圧に保た れているが, 工程内の変動に起因して水圧が極端 に変わった場合, アナライザーに送られる周期の ズレが生じて測定不能の状態となってしまう。こ うした事態では隇圧弁の調整で回避できる時もあ るが，場合によっては周期の再調整という作業が 必要となる。

・㵚ブローラインにおいてサンプリング装置内の詰 まりやアナライザーまでの道中の詰まりなどが見 られた。根本的な原因は特定できていないが, ブ ローラインパルプ中の粕が悪さをしているようで ある。
・設定ミスにより自動酸洗が行われず，セルの污れ から誤差が増大した。

しかし，上記の事例はいずれの場合も即座に対応で きるものであり, 機器や部品の交換に至るような重故 障は一度も経験しておらず安定した装置であるといえ る。

7.おわりに

新プラントの導入にあたってカヤーニのカッパーア ナライザーを設置し，これまで実測に頼っていた $\mathrm{K}$ 価の管理がオンラインで監視でき，大きな効果を得て いる。また，D０段における制御についても従来の白 色度制御に比べ品質安定に貢献しており, これは薬品 添加量の適正化，つまりは原単位削隇にもつながって いるものと認識している。特に ECF 漂白を導入した 当社にとってはその効果は大きい。今後もカッパーア ナライザーを有効利用すると共に, 品質, 生産性のさ らなる向上に努めていく次第である。 
があった場合の障害の一つになっている。

マイクロ波溇度計は, 下水道設備にて污泥の濃度測定として多数採用されてきたが, 近年はパルブ涨 度計としても使用できるとされている。

このたび, 当新潟工場で, 8 号抄紙機新設（平成 10 年 7 月稼働）に伴い，パルプ濃度計として東芝製 マイクロ波浱度計を導入した。今回，導入したマイクロ波濃度計の利点は，その測定原理（マイクロ波 による位相差方式）上，固形分（パルブ分＋各填料）が測定できることから，操業現場にとって問題と している浱度計指示と手分析した瀑度值が一致し, 具体的な濃度の傾向管理ができることが期待され, 採用となった。この装置が稼倕後 1 年余りを経過したので，その使用状況を報告する。

(本文 38 ページ)

\section{BTG 測定器の使用実績}

東海パルブ株式会社 增田 勉

パルプ蒸解における重要な指標であるカッパー価の測定には，半自動式の测定器が使用されていた。 そこで,よりリアルタイムな測定を行いカッパー価の変動傾向を正確に把握し, 蒸解釜への的確なアク ションをとることによりカッパー価の安定化を図るため, 自動カッパー価連続測定装置の設置を計画 し, 1996 年 8 月, BTG 社製自動カッパー価計を導入した。

導入に当たっては，設置上・使用上の問題点を拾い出しメーカーよりのアドバイスを参考に計画を立 案・設置工事を実施し，大きなトラブルも発生せず順調に導入できた。

この測定装置の導入により，カッパー価の安定化が図られ操業ロスの削減に大きな効果があった。そ して, さらなる活用方法の検討により品質と生産性の向上に寄与できるものと考えている。今回，カッ パー価計の設䈯にあって特に留意した点と, この 3 年間の使用状況, そしてメンテナンスの現状につい て報告する。

(本文 43 ページ)

\section{カヤー二測定器の使用実績}

\section{北越製紙株式会社新潟工場 工䅄部 杉浦 太郎}

北越製紙新潟工場は, 1998 年 7 月のオンコーターマシン 8 号抄紙機の運転に先駆け, 1997 年 11 月にク ヴァナ社の ITC (Isothermal Cooking) 蒸解金, 1998 年 2 月に日産 1,200トンの新晒ライン（E系）を 稼倠させた。

新ブラントは地域との共生を主眼とし環境負荷へ最大の配虑をした結果，世界の主流となりつつある ECF（Elemental Chlorine Free）漂白を大規模ブラントとしては日本で初めて採用した。これに伴い, ECF パルプの品質安定と漂白薬品原単位削隇を目的にオンラインカッパーアナライザーを設置し監視 及び制御を行うこととした。

カッパーアナライザーの用途として, 蒸解釜ブローライン, 未晒酸素漂白段入口, 同出口の 3 筒所にお いては監視用に,晒 D0段においては制御用に使用しており,全体的には精度良く操業できているが酸素 段出口においては, 初期設定の $\mathrm{K}$ 価範囲と操業範囲の違いによりアナライザーの指示と試験室データ に違いが生じてきた。また，D0段における制御に関しては従来の白色度制御に比べ良好な結果を得た。 装置自体は，ハード的なトラフルは 1 度もなくセルの污れについても自動酸洗装置で充分対応できノ ーメンテに近い状態で使用できている。

(本文 49 ページ) 